\title{
Prospective stem cell lines as in vitro neurodegenerative disease models for natural product research
}

Nur Izzati Mansor 1,2, Nuratiqah Azmi ${ }^{1,2}$, King-Hwa Ling ${ }^{1,2}$, Rozita Rosli ${ }^{1,2,3}$,

Zurina Hassan ${ }^{4}$ and Norshariza Nordin ${ }^{1,2,{ }^{*}}$

${ }^{1}$ Medical Genetics Unit, Department of Biomedical Science, Faculty of Medicine and Health Sciences, Universiti Putra Malaysia, Serdang, Selangor, Malaysia.

${ }^{2}$ Genetics \& Regenerative Medicine Research Centre, Faculty of Medicine and Health Sciences, Faculty of Medicine and Health Sciences, Universiti Putra Malaysia, Serdang, Selangor, Malaysia.

${ }^{3}$ UPM-MAKNA Cancer Research Laboratory, Institute of Bioscience, Universiti Putra Malaysia, Serdang, Selangor, Malaysia.

${ }^{4}$ Centre for Drug Research, Universiti Sains Malaysia, Gelugor, Penang, Malaysia.

*Correspondence: shariza@upm.edu.my; Tel.: +603-89472650

Received: 29 December 2018; Accepted: 12 March 2019; Published: 23 March 2019

Edited by: Raghava Naidu Sriramaneni (University of Wisconsin, WI, USA)

Reviewed by: Narisorn Kitiyanant (Mahidol University, Thailand);

Li-Foong Yoong (RIKEN Brain Science Institute, Japan)

https://doi.org/10.31117/neuroscirn.v2i1.25

\begin{abstract}
The use of in vitro model for screening pharmacological compounds or natural products has gained global interest. The choice of cells to be manipulated plays a vital role in coming up with the best-suited model for specific diseases, including neurodegenerative diseases (ND). A good in vitro ND model should provide appropriate morphological and molecular features that mimic ND conditions where it can be used to screen potential properties of natural products in addition to unravelling the molecular mechanisms of ND. In this mini review, we intend to demonstrate two prospective stem cell lines as the potential cell source for in vitro ND model and compare them to the commonly used cells. The common source of cells that have been used as the in vitro ND models is discussed before going into details talking about the two prospective stem cell lines.
\end{abstract}

Keywords: Neurodegenerative diseases; Natural products; Stem cell; In vitro ND models;

C2019 by Mansor et al. for use and distribution in accord with the Creative Commons Attribution (CC BY-NC 4.0) license (https://creativecommons.org/licenses/by-nc/4.0/), which permits unrestricted non-commercial use, distribution, and reproduction in any medium, provided the original author and source are credited. 


\section{INTRODUCTION}

Neurodegenerative diseases (ND) is the term used for various conditions, primarily marked by the loss of nerve cells, resulting in functional impairment of neurons. The progressive degeneration and/or death of nerve cells and the limited ability of the brain to selfrepair subjects ND to be incurable. As degenerative diseases are often linked to differentiation stimulation, many therapeutic strategies for neurodegenerative diseases have been studied with emphasis on the regulation of cell differentiation [1]. Although the neurological mechanisms of action are still not fully understood, it was previously reported that the cell differentiation, survival, protection and regeneration were shown to be influenced by the neurotrophins and growth factors, especially the nerve growth factors (NGF) and brain-derived neurotrophic factors (BDNF) [2].

Herbal medicine research has gained increasing interest globally for their therapeutic potentials. Extensive practise of herbal medicine provides promising approaches to current therapies for ND. Researchers revealed that the presence of phytochemicals in herbal extracts including total alkaloids, phenolics, flavonoids, tannins and terpenic acids, exhibit promising antiinflammatory, antioxidant, neuroregenerative and neuroprotective properties, as well as anticholinesterase and neurotrophic-like activities with lesser adverse effect. Furthermore, some of them promote cell survival and improve cognitive functions by directly regulating amyloidogenesis and apoptotic signalling pathways. Some promising natural products that may have therapeutic potentials for the treatment of ND and the cell lines used as the in vitro models are summarised in Table 1.

Hence, screening of pharmacological compounds or herbal extracts for their neuro-pharmacology properties would provide the means to gain knowledge on the morphological features and molecular mechanisms of ND in addition to gaining insights towards the development of various types of treatment for these diseases. Initial screening of these properties could be first done through the use of appropriate in vitro ND model, thus creating the best suited in vitro models for ND in cell culture is invaluable and essential. Table 1 shows the cell lines that have been used as ND models to screen the neurotherapeutic potential of phytochemicals from natural products. There are several approaches to generating in vitro models for neurodegenerative diseases based on aetiology and mechanisms involved in the diseases. In attempting to mimic the same phenomenon occurring in animal models of ND, the synthetic compounds/toxins which possess neurotoxicity activity are introduced to cultured cells to induce cell injury and activate the apoptotic signalling pathways that are correlated with the disease of interest. The most commonly used synthetic compounds/toxins are (1) $\beta$-amyloid, (2) glutamate, (3) 6-hydroxydopamine (6-OHDA), (4) 1-methyl-4phenylpyridine (MPP+), (5) rotenone, and (6) hydrogen peroxide (Table 2). Another approach is by genetic modification such as (1) Presenilin 1 (PSEN1); (2) Presenilin 2 (PSEN2) []ㅡ; ; and (3) Amyloid precursor protein genes [4]. Besides the choice of a neurotoxic agent used, the source for neural/neuronal cells also plays an important role in deciding the appropriate in vitro model to use.

In this research note, we aim to demonstrate the suitability of using stem cell lines, namely the mouse embryonic (46C) and rat full-term amniotic fluid (R3) stem cell lines, as the prospective source of neuronal cells in creating the models that could later be used to aim for screening neuro-pharmacology properties of an extract or natural compound, as opposed to the commonly used cell lines. In doing so, the features and properties of the commonly used cell lines as the cell source for developing in vitro model for ND is discussed and compared to that of $46 \mathrm{C}$ and R3 lines.

\section{COMMONLY USED CELL LINES FOR IN VITRO ND MODEL}

The commonly available in vitro models that are widely used for ND studies come from three cell sources: (1) Human neuroblastoma (SH-SY5Y); (2) immortal rat 
hippocampal; and (3) Induced pluripotent stem cell

lines.

Table 1: Neurotherapeutic potential of phytochemicals from natural products

\begin{tabular}{llll}
\hline Plant source & Phytochemical & Pharmacological effects & Medicinal use \\
\hline Ginkgo biloba & Ginkgolide B & ROS scavenger inhibits NF-kB activation & Neuroprotection, \\
& & and PI3K/Akt signalling, inhibition of & neurodegeneration \\
& & apoptotic protein expression, activates & disease, antioxidant \\
& & Wnt/ $\beta$-catenin signalling pathway. &
\end{tabular}

In vitro model used: Rat primary

cerebellar neuron cells; neural stem cells

of the postnatal mammalian

subventricular zone; rat primary

hippocampal neuronal cells; human

neuroblastoma (SH-SY5Y) cells.

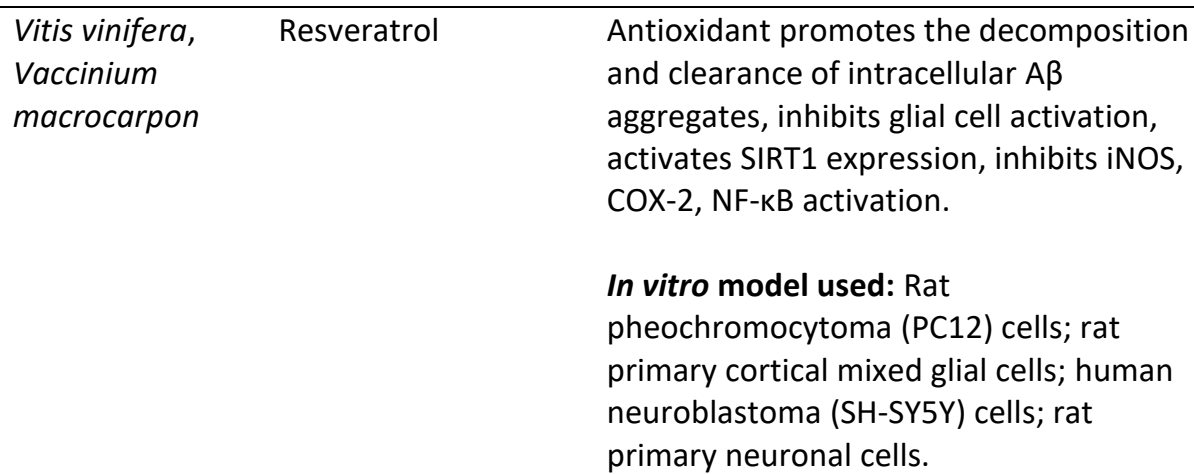

\begin{tabular}{|c|c|c|}
\hline \multirow[t]{2}{*}{$\begin{array}{l}\text { Huperzia } \\
\text { serrata }\end{array}$} & Huperzine A & $\begin{array}{l}* \text { AChE inhibitor, reduces protein levels of } \\
\text { IL-1 } \beta \text { and TNF- } \alpha \text {, inhibits NF-KB activation, } \\
\text { and increases BDNF and NGF level. }\end{array}$ \\
\hline & & $\begin{array}{l}\text { In vitro model used: Rat } \\
\text { pheochromocytoma (PC12) cells; rat } \\
\text { primary cortical neuronal cells. }\end{array}$ \\
\hline
\end{tabular}

Neuroprotection,

[10-21] neurodegeneration disease, antioxidant

Neuroprotection, neurodegeneration disease, antioxidant, anti-inflammation
Inhibits $A \beta$-induced oxidative stress through activation PI3K/Akt signalling, suppresses the expression of MAPK and JNK, ROS scavenger.

In vitro model used: Human neuroblastoma (SH-SY5Y) cells; murine BV-2 microglial cells; rat pheochromocytoma (PC12) cells; rat primary hippocampal neuronal cells.

Curcuma longa Curcumin Increases BDNF level, ROS scavenger,
prevents $A \beta$ fibrils, inhibits COX-2 and NF$\mathrm{KB}$ activation activates $\mathrm{PKC} / \mathrm{ERK}$-mediated CREB regulation.

Neuroprotection,
neurodegeneration
disease, antioxidant

$[\underline{27}-\underline{34}]$
Antioxidant, anti-
inflammation,
neurogenesis,
neuritogenesis 
Table 2: The most common synthetic compoundsm/toxins used in ND in vitro models

\begin{tabular}{|c|c|c|}
\hline Common synthetic compounds/toxins & Disease model * & References \\
\hline$\beta$-amyloid & $A D$ & {$[\underline{4}, \underline{42}-\underline{44}]$} \\
\hline Glutamate & $A D$ & {$[\underline{45}]$} \\
\hline 6-hydroxydopamine (6-OHDA) & PD & {$[\underline{46}]$} \\
\hline 1-methyl-4-phenylpyridine (MPP+) & PD & {$[\underline{46}]$} \\
\hline Rotenone & PD & [47] \\
\hline Hydrogen peroxide & $\begin{array}{c}\text { ND associated with oxidative stress, } \\
\text { especially PD and AD }\end{array}$ & {$[\underline{13}, \underline{27}, \underline{34}, \underline{48}-\underline{51}]$} \\
\hline
\end{tabular}

*AD = Alzheimer 's disease; PD = Parkinson's Disease

Human neuroblastoma cell lines (SH-SY5Y) has been used widely in neuroscience research. SH-SY5Y cells are a subclone of the parental neuroblastoma SK-N-SH cell lines that were derived from bone marrow biopsies, consists of neuroblast-like and epithelial-like cells [52]. SH-SY5Y cells consist 47 chromosomes, making it a stable karyotype and able to differentiate into mature neurons by induction with retinoic acid (RA) or neurotrophins such as brain-derived neurotrophic factor (BDNF) [ $\underline{53}$ ]. SH-SY5Y has been used to establish in vitro model for Alzheimer Disease $(A D)$ and Parkinson Disease (PD), as well as other neurodegenerative diseases. SH-SY5Y can express functional neuronal subtypes when differentiate, as such into synaptic structures, functional axonal vesicle transport and express neuronal markers NeuN, class III $\beta$-tubulin and synaptic vesicle protein 2 (SV2) [54]. A study conducted by Constantinescu and coworkers showed that SH-SY5Y was successfully induced into dopaminergic neurons by RA at a concentration of $10 \mu \mathrm{M}$ for a few days [55]. This finding was in a good agreement with another study that reported the presence of tyrosine hydroxylase (TH) (a marker for dopaminergic neurons) gene expression post-differentiation [ㄷ]].

Besides RA, the SH-SY5Y cell line also has been used as a model to study PD when exposed to rotenone, a specific inhibitor of mitochondrial complex I that can cause mitochondria impairment leading to increasing in oxidative stress. The administration of rotenone has been observed to induce cell apoptosis and accumulation of reactive oxidative species (ROS) $[\underline{49}, \underline{57}, \underline{58}]$. Another study also showed that treatment of SH-SY5Y with rotenone might involve mitochondriaand endoplasmic reticulum-dependent caspase pathways, promoting cell death in concentration- and time-dependent manner [57]. Rotenone-induced $\mathrm{SH}$ SY5Y neurons were also used to evaluate the protective effect of antioxidant property of the phenolic compound. The phenolic compound was found to exert protective effects against the cytotoxicity of rotenone and increased the cellular GSH contents [ $\underline{58}$ ].

Interestingly, A $\beta$-induced oxidative stress in SH-SY5Y also elicits the same mechanisms [료] as observed in rotenone-induced cell damage. Using this model, treatment with antioxidant salidroside was found to restore cell survival and enhance the expression of antioxidant genes [28]. In another study, the SH-SY5Y cell line was used to test the effect of asiatic acid of Centella asiatica in inhibiting glutamate-induced $\mathrm{SH}$ SY5Y from undergoing apoptosis and reducing ROS activity when compared to the untreated cells [45]. These exciting features of a cytotoxic-induced SH-SY5Y cell line may benefit in finding the treatment regime for $P D$ and $A D$. However, this model does not mimic the real scenario in human ND due to different cell signalling pathways by cancer genes [59].

Due to the high demand for using normal brain cells in vitro, that express specific neuronal subtypes, immortal rat hippocampal cell lines were studied. These cells were immortalised using retroviral-mediated oncogene transduction Simian virus 40 large tumour antigens [60]. 
The cells have two distinct properties which are: (1) restricted proliferation; and (2) ability to differentiate after completion of neuronal division. Immortal rat hippocampal cell lines exhibit neural subtype markers such as glial fibrillary acid protein (GFAP), Neurofilament protein (NFP) and synthesise neurotrophic factors [60]. Since the cells were originated from the hippocampus, which is responsible for cognitive and memory function, these cell lines are suitable for $A D$ model. These cells have been used to evaluate the neuroprotection activity of herbal medicines intended for the treatment of ND. A study showed that four traditional Oriental medicinal herbs protect the rat hippocampal cells from glutamateinduced toxicity by reducing the ROS production and increasing cell viability [61]. Although these cell lines provide a promising approach to evaluate the neuroprotection and neuroregeneration potential of herbal medicines, its action is limited to the animal $A D$, and it cannot induce the full range of deficits seen in human with $A D$ due to lack of receptor for human $A \beta$ peptides [무].

The reprogramming of the somatic cells to induced pluripotent stem cells (iPSCs) to model ND pathogenesis in vitro has been established and accepted worldwide. The recent review article discusses the potential use of PD-specific iPSCs to model the pathogenesis of the disease due to genetic variants carried in iPSCs [62]. In a comparison study between the ability of iPSC and embryonic stem cells (ESCs) to differentiate into dopaminergic neurons revealed that iPSCs show higher differentiation ability compared to ESCs [63]. These findings show that iPSCs can provide a promising source for dopaminergic neurons in modelling PD in vitro. A recent study shows that disease-/patient-specific iPSCderived neurons can provide a better understanding of the drug screening. A study conducted by Cooper et al. showed neurons from PD patients that carrying mutations in the PINK1 or LRRK2 genes exhibited oxidative stress and mitochondria impairment [64]. In addition, the $A D$ model was also established from primary human fibroblast cells collected from familial Alzheimer's disease (FAD) patient and was reprogrammed into iPSC. From this iPSC, two AD in vitro models were established with different clones using Presenilin 1 (PSEN1); (2) Presenilin 2(PSEN2) mutations. The genetic modified-iPSCs were then undergoing neural differentiation to model in vitro AD pathogenesis [3]]. However, this model is time-consuming with a high risk of mutations [59].

\section{PROSPECTIVE STEM CELL LINES AS AN IN VITRO ND MODEL}

Unlike SH-SY5Y cells and immortal rat hippocampal cells, stem cells are unique cells with the capacity to self-renew [65] and can be differentiated into a vast variety of cell types including neurons in vitro [66]. Several studies have shown the beneficial effect of stem cells in degenerative diseases due to their capacity to differentiate into any types of cells and also their ability to secrete trophic factors that can reverse the damaged tissues [67]. Furthermore, stem cells become precious tools to establish in vitro model of ND and to study the therapeutic strategies owing to their capability to differentiate into any types of cells. To expand the choice of stem cell use as the prospect cells for establishing ND in vitro models, we are exploring and manipulating the properties of mouse embryonic stem cell (mESCs), 46C, and rat amniotic fluid stem cell (AFSCs), R3, lines. $46 \mathrm{C}$ is a mESCs transgenic line that carries a green fluorescent protein (GFP) knocked-in into the open reading frame of a transcription factor gene, Sox1, a marker for neural precursor cells (NPCs) [68]. Meanwhile, R3 is our in-house established AFSCs generated from rat full-term amniotic fluid. Both $46 \mathrm{C}$ and R3 have been shown to have the ability to differentiate into neurons [흐-72].

Mouse ESCs can be acquired from (1) dissociated morulae [72]; (2) intact blastocysts [133]; and the inner cell mass (ICM). Generally, mESCs were isolated from E3.5 ICM of the mouse blastocyst [74] into tissue culture and propagating them in the presence of leukaemia inhibitory factor (LIF) [75] or murine embryonic fibroblast (MEF) feeder layer cells [76]. ESCs are characterised by their ability to proliferate indefinitely in vitro while maintaining their pluripotency properties 
[73]. ESCs can differentiate into the derivatives of the three primary germ layers, which are: (1) mesoderm; (2) endoderm; and (3) ectoderm [77-79].

Three fundamental transcription factors are involved in maintaining the pluripotency and self-renewal of ESCS, namely: (1) Oct4, belongs to POU family transcription; (2) Sox2, a member of SRY-related HMG box (Sox) family; and (3) Nanog, from the homeobox DNA binding family [80-83]. Oct4 gene is highly expressed in the ICM of the blastocyst, during early embryogenesis [84], as well as in pluripotent cells and it plays a crucial role in the cell fate determination [85]. Another transcription factor, Sox2 plays a crucial role in embryonic development and is also associated with pluripotency of ESCs [이. Sox2 is also involved in the proliferation of precursor cells and differentiation of neuronal specific subtypes during the development of the central nervous system (CNS) [86]. Similar to Oct4 and Sox2, Nanog is also essential in the maintenance of pluripotency and self-renewal of ESCs [주, $\underline{88}]$. In addition, Silva et al. and Mitsui et al. reported that Nanog is a key factor in the development of ICM and germ cells, suggesting its involvement in maintaining the pluripotency and self-renewal of the cells $[\underline{87}, \underline{89}]$. These three transcriptional genes work in the dependence manner in order to maintain self-renewal property while inhibiting the differentiation of the ESCS by co-operatively bind to their promoter and forming interrelated auto-regulatory loop $[\underline{73}, \underline{81}, \underline{82}]$.

On the other hand, amniotic fluid consists of numerous cell types derived from a growing foetus which ultimately differentiated into various cell types such as adipose, muscle, blood and neural lineage [90]. Currently, research on stem cells derived from amniotic fluid have been extensively studied. AFSCs can be obtained during the second and third trimester of pregnancy or directly after birth in human; and in the second or third week of pregnancy in mice and rats $[\underline{71}, \underline{90}, \underline{91}]$. Two major populations of stem cells were found in amniotic fluids as reported by Cananzi and co- workers, namely; (1) amniotic fluid mesenchymal stem cells and amniotic fluid stem cells (AFSC) [92]. We have successfully isolated and characterised AFSC in rats [71]. We categorised these cells as broadly multipotent stem cell based on the presence of the surface antigen, c-kit (CD117, a type III tyrosine kinase receptor of stem cell), which distinguishes it from mesenchymal stem cells [71]. The cells were observed to express Oct4 and Nanog. Our results were also supported by the study conducted by De Coppi and co-workers on the ability of rat AFSC to differentiate into the three primary germ layers: (1) mesoderm; (2) endoderm; and (3) ectoderm $[\underline{71}, \underline{90}]$

Both 46C and R3 can be directly induced to differentiate into neural lineage through the (1) formation of multicellular aggregates, embryoid bodies, EBs, by 4-/4+ protocol [69], with the addition of all-trans retinoic acid (ATRA) as the neural inducer and also via (2) monoculture adherence protocol [93]. The abilities of mESCs and rat AFSCs to differentiate into functional neuronal and neuronal supporting cell subtypes have been reported previously $[\underline{69}, \underline{71}]$. These discoveries were in good agreement with our study with $46 \mathrm{C}$ and R3 (Figure 1 and 2). Both cell lines were able to generate good quality EBs (Figure 1) and differentiate into immature and mature neurons, as well as glial cells (Figure 2). Their neurogenic potential was observed to be similar to SH-SY5Y cells and immortalised rat hippocampal cell lines based on the marker expression profile (Table 3 ). All of these cell lines express markers for post-mitotic and mature neurons, as well as glial cells.

The neurogenic properties of these cell lines have prompted us to test the suitability of their generated neurons as a tool to establish an in vitro ND model, as a prospective model for natural product research or at least for initial screening of neurotherapeutic potential of natural products. The in vitro model was established by treating R3-and 46C-derived neurons with hydrogen peroxide $\left(\mathrm{H}_{2} \mathrm{O}_{2}\right)$. 
R3
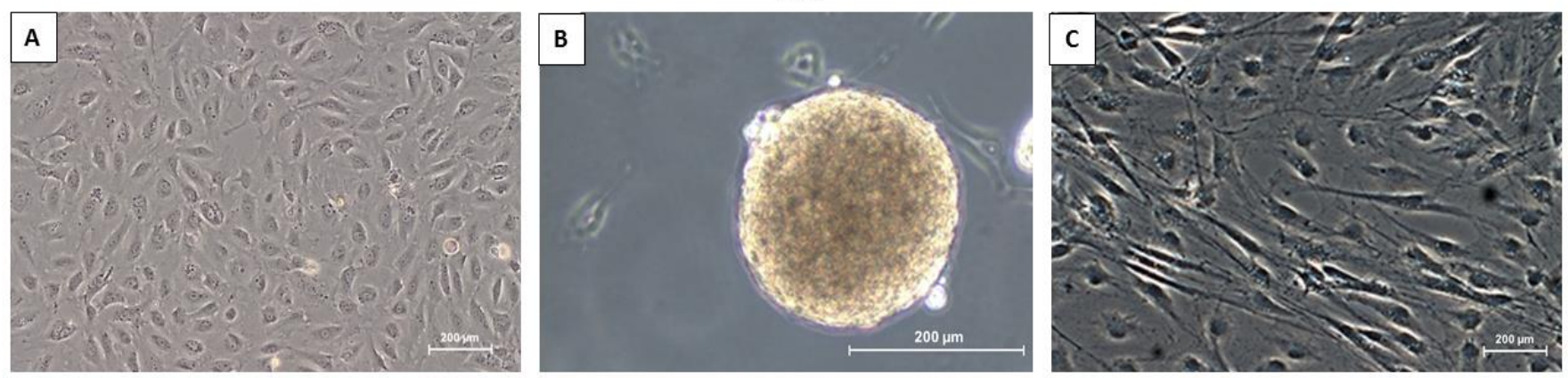

$46 C$
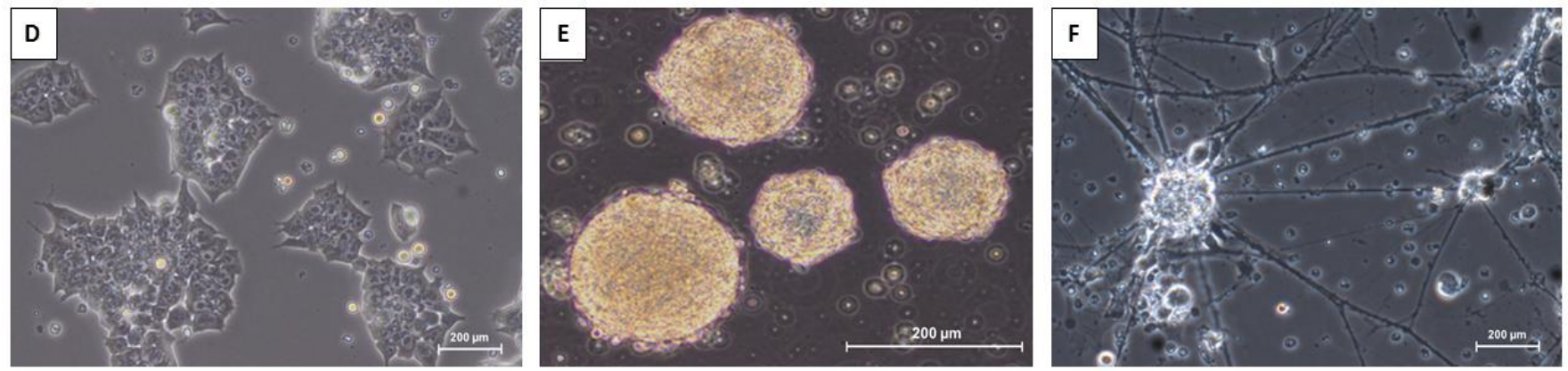

Figure 1: Differentiation of 46C and R3 after neural induction using 4-/4+ protocol. (A) Undifferentiated R3; (B) Day 4 R3derived EBs; (C) Day 6 post-plating R3-derived neurons onto gelatin-coated plate; (D) Undifferentiated 46C; (E) Day 4 46Cderived EBs; and (F) Day 8 post-plating 46C-derived neurons onto PDL/Laminin-coated plate. The scale bars represent $200 \mu \mathrm{m}$ for micrographs.

$\mathrm{H}_{2} \mathrm{O}_{2}$ was chosen for the fact that it has been used as the most common toxin to induce oxidative stress condition which is the general hallmark in ND conditions,

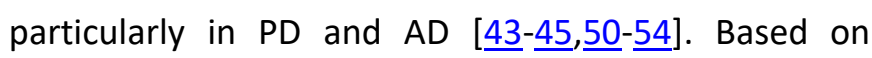
cytotoxicity assay using MTT (Figure 3A), high concentrations of $\mathrm{H} 2 \mathrm{O} 2$ ( $1500 \mu \mathrm{M}$ for $46 \mathrm{C}$ and $2000 \mu \mathrm{M}$ for R3) were chosen. Our data showed a significant increase in ROS activity when the neurons were treated with $\mathrm{H} 2 \mathrm{O} 2$ at these concentrations (Figure 3). Our results indicate a prospective success of establishing ND models in vitro by stimulating the production of reactive oxygen species (ROS). These findings clearly demonstrate the potential of these stem cell lines to provide good sources for an ideal in vitro model that could be mimicking ND phenomenon. Unlike SH-SY5Y, which is a cancerous cell line, these stem cell lines may provide more reliable sources of neurons as they represent a normal condition before the pathogenicity of ND develops. The effects of using more toxins such as those described in Table 2 should be carried out in the effort to characterise new in vitro models in future studies. Nevertheless, more in-depth investigations looking at different perspectives of an in vitro ND model are required before one can use it as the model. In a nutshell, these cell lines may be efficiently manipulated to establish models that would be applicable for initial screening of drugs or neurotherapeutic molecules of natural products, and fundamental studies before invivo pre-clinical studies to take part. 
R3
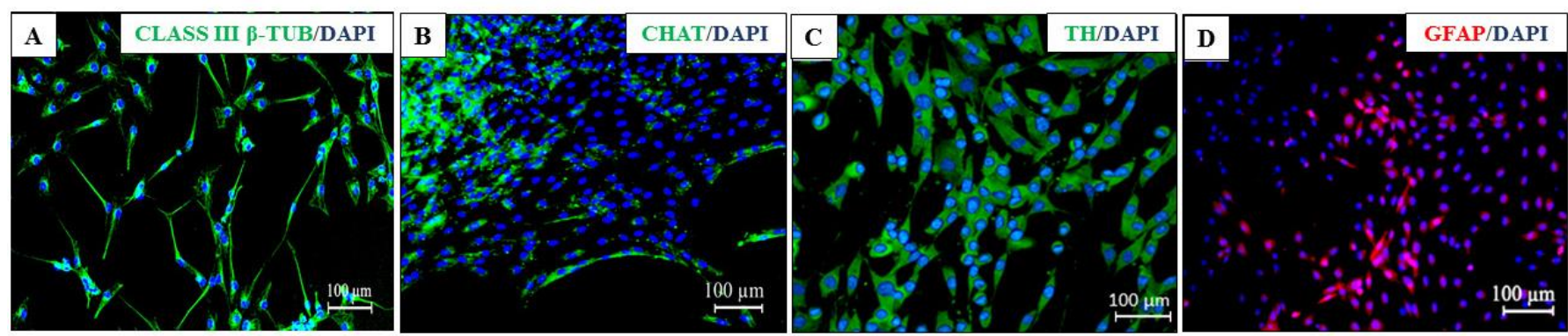

46C
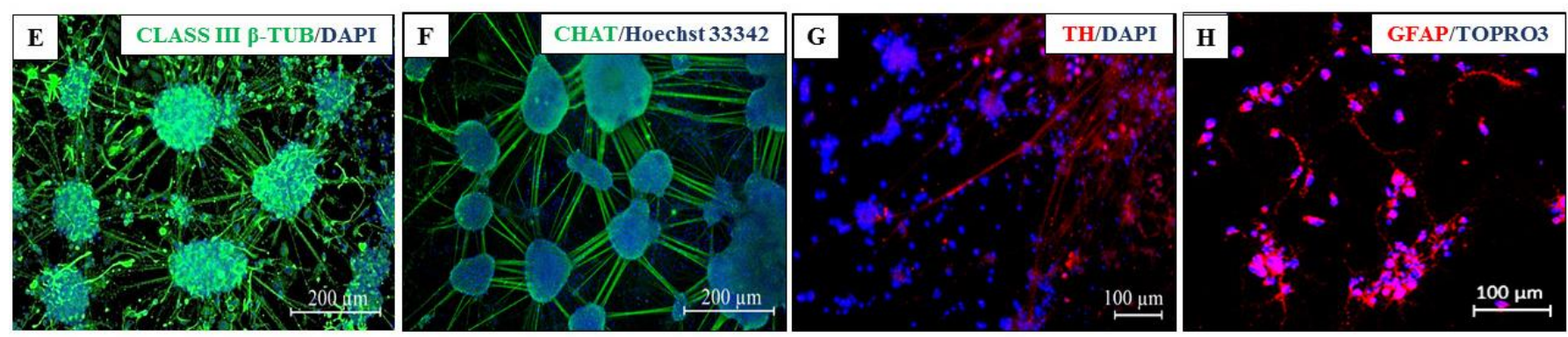

Figure 2: Immunostaining of neural specific markers after neural differentiation of R3 and 46C from both monolayer adherent and 4-/4+ protocols. (A) and (E) are immunostaining of class III ß-tubulin (post-mitotic neurons); (B) and (F) are immunostaining of choline acetyltransferase, CHAT, (cholinergic neurons), (C) and (G) are expression of tyrosine hydroxylase, $\mathrm{TH}$, (dopaminergic neurons), and (D) and (H) immunostaining of glial fibrillary acidic protein, GFAP, (astrocytes) in R3 and 46C-derived neurons, respectively. Nuclei were counterstained with DAPI, TOPRO3 or Hoechst 33342 (blue). The neural specific markers highly indicate that adherent monoculture and 4-/4+ protocol have efficiently generated not only neuronal cells but also neuron supporting cells (glial cells) in R3 and 46C, respectively. R3-derived cells were from D12 (A) and D8 (B, C and D) neural cells plated onto gelatin-coated plates and 46C-derived cells were from D4 (E and F) neural cells post-plated onto PDL/Laminin-coated plates and D14 (G and H) post-plated onto gelatin-coated plates. Class III ß-tubulin, TH and GFAP positive cells were obtained through monolayer adherent method; while ChAT-positive cells were obtained via 4-/4+ method. The scale bars represent 100 and $200 \mu \mathrm{m}$ for micrographs.

Table 3: Comparison of marker expression profiles of SH-SY5Y and rat immortalised hippocampal cells to $46 \mathrm{C}$ and $\mathrm{R} 3$

\begin{tabular}{|c|c|c|c|}
\hline $\begin{array}{l}\text { Marker expression / } \\
\text { Cell lines }\end{array}$ & Post-mitotic neurons & Mature neurons & Glial Cells \\
\hline $\begin{array}{l}\text { Human neuroblastoma } \\
\text { (SH-SY5Y) }\end{array}$ & $\begin{array}{l}\text { NeuN and } \\
\text { Class III } \beta \text {-tubulin [20] }\end{array}$ & $\begin{array}{l}\text { Tyrosine hydroxylase (TH) }[\underline{56}] \\
\text { Synaptic vesicle protein } 2 \text { (SV2) [을 }\end{array}$ & - \\
\hline $\begin{array}{l}\text { Rat immortalised } \\
\text { hippocampal cells }\end{array}$ & - & Neurofilament protein (NFP) [60] & $\begin{array}{l}\text { Glial fibrillary acid } \\
\text { protein (GFAP) [60] }\end{array}$ \\
\hline Embryonic stem cell (46C) & Class III ß-tubulin & $\begin{array}{l}\text { Choline acetyltransferase (ChAT) } \\
\text { Tyrosine hydroxylase (TH) }\end{array}$ & $\begin{array}{l}\text { Glial fibrillary acidic } \\
\text { protein (GFAP) }\end{array}$ \\
\hline Rat amniotic fluid cell (R3) & Class III ß-tubulin & $\begin{array}{l}\text { Choline acetyltransferase (ChAT) } \\
\text { Tyrosine hydroxylase (TH) }\end{array}$ & $\begin{array}{l}\text { Glial fibrillary acidic } \\
\text { protein (GFAP) }\end{array}$ \\
\hline
\end{tabular}




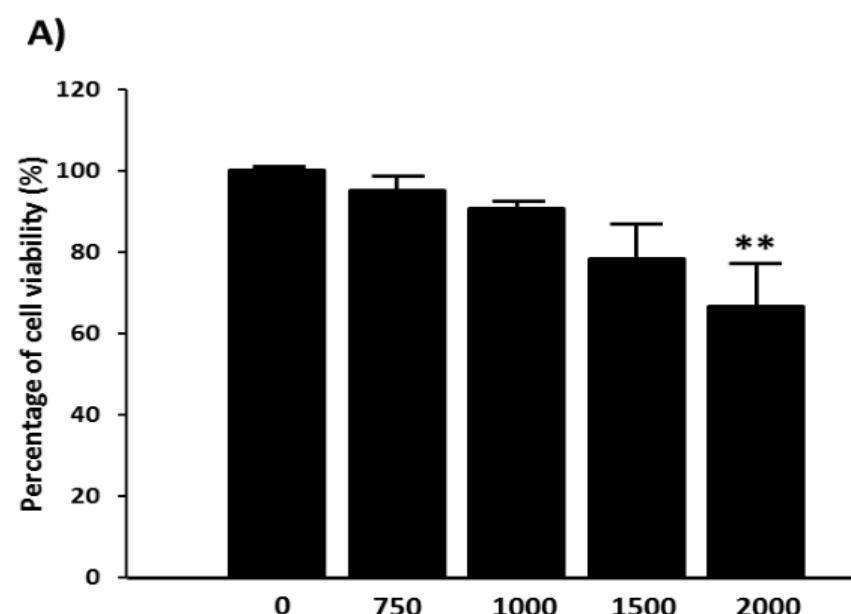

Concentration of Hydrogen peroxide $\left(\mathrm{H}_{2} \mathrm{O}_{2}\right) \mu \mathrm{M}$

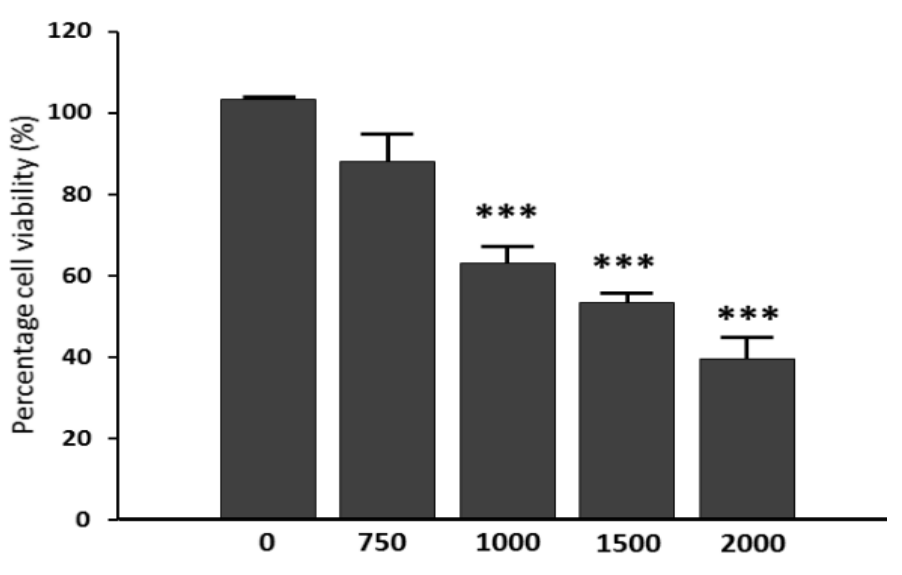

Concentration of Hydrogen peroxide $\left(\mathrm{H}_{2} \mathrm{O}_{2}\right) \mu \mathrm{M}$

\section{R3-derived neurons}

46C-derived neurons
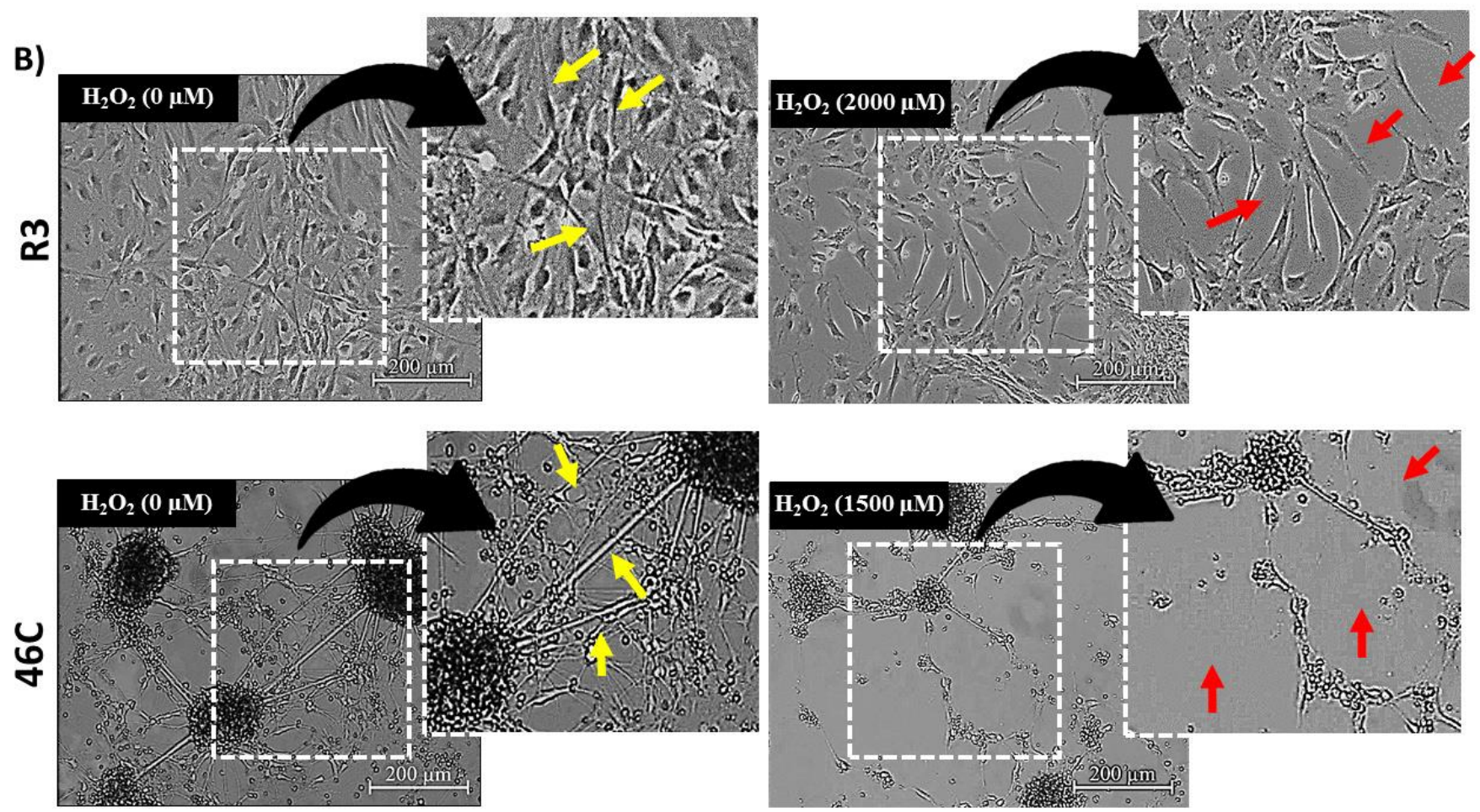

Figure 3: (A) The effect of different concentrations of $\mathrm{H}_{2} \mathrm{O}_{2}$ on $\mathrm{R} 3$ - and 46C-derived neurons expressed as the percentage of cell viability by MTT assay. Errors bars (I) indicate \pm standard error of mean from 3 independent experiments, each with 3 technical replicates $(n=3)$ where $* * *$ indicates $p<0.001$ and $* *$ indicates $p<0.01$ (One way ANOVA: Tukey's test multiple comparisons) compared to untreated neurons. (B) Morphology of untreated $\left(0 \mu \mathrm{M} \mathrm{H}_{2} \mathrm{O}_{2}\right)$ with neurite projections (indicated by yellow arrows); 2000 and $1500 \mu \mathrm{M} \mathrm{H}_{2} \mathrm{O}_{2}$-treated day 8 post-plated R3-derived neurons and day 4 post-plated 46C-derived neurons, respectively, after $24 \mathrm{~h}$ treatment. The neurons were damaged upon treatment with $\mathrm{H}_{2} \mathrm{O}_{2}$. Neurite projections damaged in neuronal culture treated with $\mathrm{H}_{2} \mathrm{O}_{2}$ (indicated by red arrows). The scale bars represent $200 \mu \mathrm{m}$ for micrographs. ROS activity was assessed by H2DCF-DA assay, as depicted in the histogram (C, next page) and percentage of ROS generation versus neurons graph (D, next page). (C, next page) Intracellular ROS generation within the cells labelled with 2', 7'dichlorodihydrofluorescein diacetate (H2DCF-DA) was measured by flow cytometry. Intracellular ROS oxidized H2DCF-DA into fluorescent 2', 7'- dichlorodihydrofluorescein diacetate (DCF). Continued on next page. 
C) i) R3-derived neurons
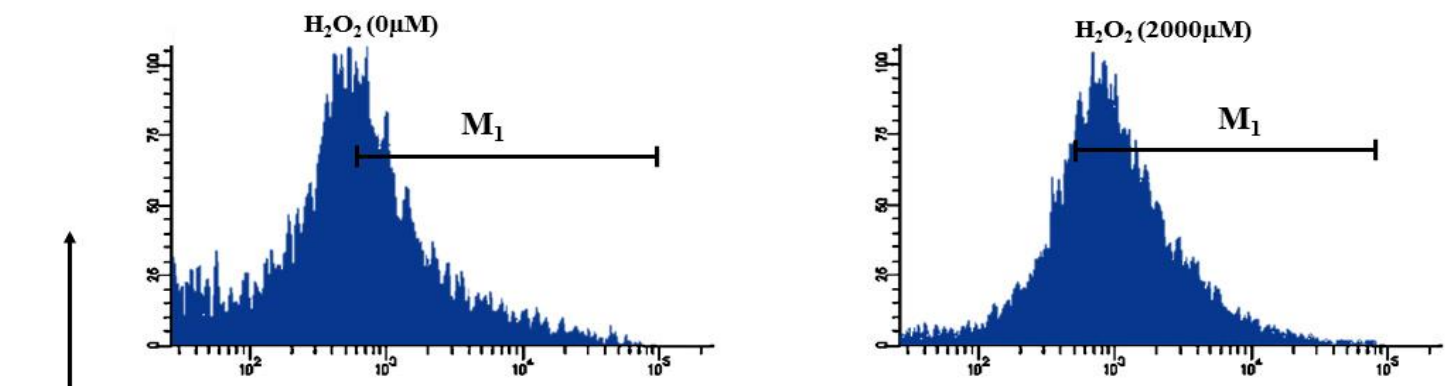

ii) 46C-derived neurons
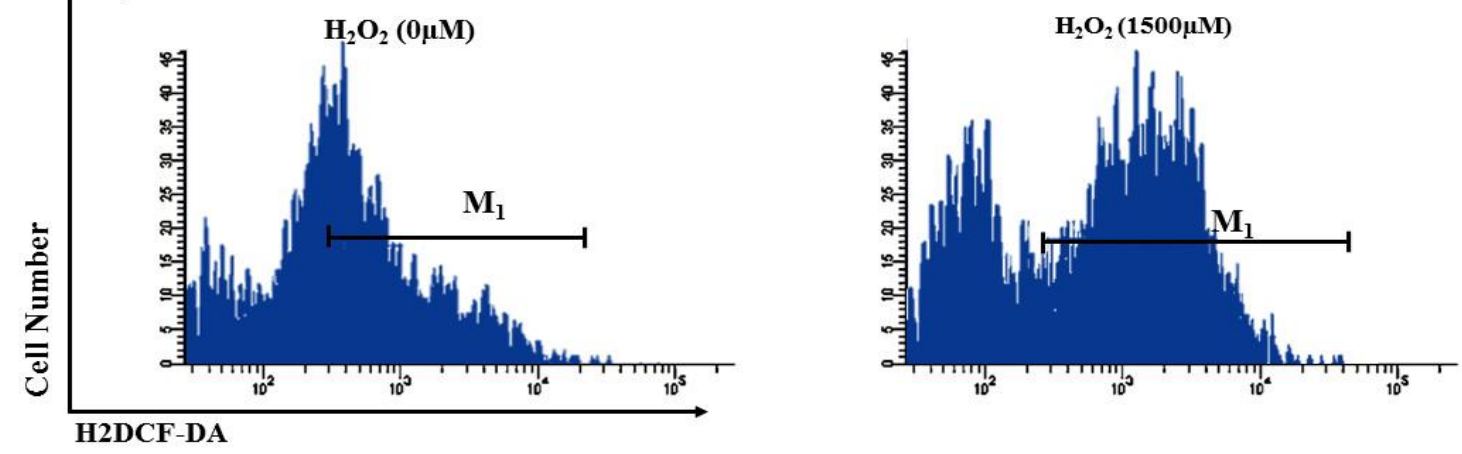

D) Intracellular ROS generated from $\mathrm{H}_{2} \mathrm{O}_{2}$-induced neurons
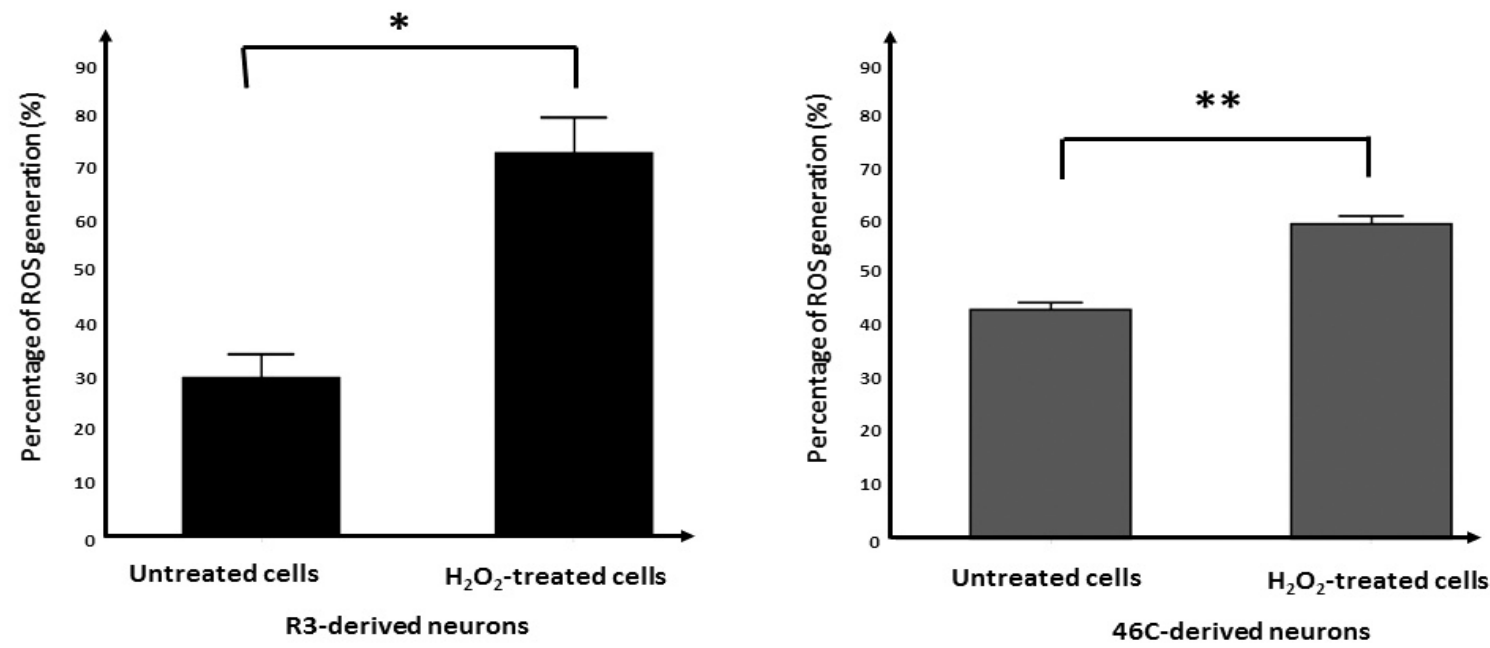

\section{Continue from previous page.}

Figure 3: In our study, the neurons were pre-incubated with $\mathrm{H}_{2} \mathrm{O}_{2}$ at the concentrations of $0 \mu \mathrm{M}$ which served as control, 1500 and $2000 \mu \mathrm{M}\left(46 \mathrm{C}\right.$ - and R3-derived neurons, respectively) for $24 \mathrm{~h}$ at $37^{\circ} \mathrm{C}$, then incubated with DCFH-DA for $45 \mathrm{~min}$ at $37^{\circ} \mathrm{C}$. The X-axis of H2DCF-DA histogram represents the H2DCF-DA intensity, while the $Y$-axis represents the cell counts in corresponding DCF fluorescence intensity. The percentage of ROS release within the cell population was shown by the shift of histogram peak to $\mathrm{M}_{1}$ zones, defined as positive cells. Our results show that the peaks of $\mathrm{H}_{2} \mathrm{O}_{2}$-treated neurons at a concentration of $1500 \mu \mathrm{m}$ and $2000 \mu \mathrm{M}$, were gradually shifted to the right of $\mathrm{M}_{1}$ zones compared to the untreated neurons $\left(0 \mu \mathrm{M} \mathrm{H}_{2} \mathrm{O}_{2}\right)$, reflecting an increased level of intracellular ROS within the cell population (D). 2000 and $1500 \mu \mathrm{M}$ of $\mathrm{H}_{2} \mathrm{O}_{2}$ induced a significant increase in ROS level of R3- and $46 \mathrm{C}$-derived neurons, respectively, as compared to untreated neurons (control). The values represent the percentage of generated ROS. The error bars indicate mean \pm Standard deviation (SD) from 1 independent experiment with 3 technical replicates $(n=3)$ for R3-derived neurons and 46C-derived neurons, where $* *$ indicates $p<0.01$ and * indicates $p<0.05$ (Student's $t$-test). 


\section{CONCLUSIONS AND FUTURE PROSPECTS}

Neurons derived from animal stem cell lines may serve as high prospective cells to be utilised in the establishment of an in vitro ND model. They may provide better models for initial screening of neuropharmacology properties of drugs or natural products from a more reliable source that represents a normal condition compared to using cancerous cell line such as the neuroblastoma cell line. Although these two animal stem cell lines retained the capacity for neuronal and glial differentiation and can be grown for an extended period, data on human stem cells would be more appropriate as it is more reflective of human scenario and would be more suitable for medical applications. Thus, further studies using human stem cells should be looked into in the future.

Supplementary Materials: The following are available online at https://neuroscirn.org/ojs/index.php/nrnotes/article/view/25. Method S1: Propagation of $46 \mathrm{C}$ mouse embryonic stem (mES) cell and Rat amniotic fluid stem cell (R3); Method

S2. Neural differentiation assay; Method S2a. Neural differentiation assay trough EBs formation; Method S2b. Neural differentiation assay through adherent monoculture; Method S3. Immunocytochemistry; Method S4. Analysis of intercellular reactive oxygen species (ROS); Table S1. List of antibodies used for immunocytochemistry.

Acknowledgments: We would like to express our gratitude to Ministry of Agriculture of Malaysia (MOA) for financial support through NKEA Research Grant Scheme (NRGS) [Project number: NH1014D045] and to Graduate Research Fellowship (GRF), Universiti Putra Malaysia (UPM). The authors also wish to thank the colleagues in Stem Cell Research Lab and Medical Genetics Lab, Faculty of Medicine and Health Science, UPM, Malaysia.

Author Contributions: All authors read and approved the final manuscript. $\mathrm{NI}$ and $\mathrm{NN}$ designed the experiments; $\mathrm{NI}$ performed the experiments; NN, KHL, RR, ZH contributed reagents/analytical tools; $\mathrm{NI}$ and $\mathrm{NN}$ analysed data and drafted the article.

Conflicts of Interest: The authors declare that they have no conflict of interest.

\section{References}

1. Liu B, Hong J. Role of Microglia in Inflammation-Mediated Neurodegenerative Diseases: Mechanisms and Strategies for Therapeutic Intervention. J Pharmacol Exp Ther. 2003;304(1):1-7. https://doi.org/10.1124/ipet.102.035048.logical

2. Yamazaki M, Chiba K. Neurotrophic Effects of Genipin on Neuro2a Cells. J Heal Sci. 2005;51(6):687-692. https://doi.org/10.1248/ihs.51.687

3. Yagi T, Ito D, Okada Y, Akamatsu W, Nihei Y, Yoshizaki T, et al. Modeling familial Alzheimer' s disease with induced pluripotent stem cells. Hum Mol Genet. 2011;20(23):4530-4539. https://doi.org/10.1093/hmg/ddr394

4. Delacourte A, Sergeant N, Buée L. In vitro models of age-related neurodegenerative disorders. Exp Gerontol. 2003;38(1112):1309-1317. https://doi.org/10.1016/i.exger.2003.09.010

5. Xiao Q, Wang C, Li J, Hou Q, Li J, J M, et al. Ginkgolide B protects hippocampal neurons from apoptosis induced by betaamyloid 25 - 35 partly via up-regulation of brain- derived neurotrophic factor. Eur J Pharmacol. 2019;647(1-3):48-54. https://doi.org/10.1016/j.ejphar.2010.08.002

6. Oyama Y, Chikahisa L. Ginkgo biloba extract protects brain neurons against oxidative stress induced by hydrogen peroxide. Brain res. 1996;712:349-352. https://doi.org/10.1016/0006-8993(95)01440-3

7. Guo M, Suo Y, Gao Q, Du H, Zeng W, Wang Y. The protective mechanism of Ginkgolides and Ginkgo flavonoids on the TNF- $\alpha$ induced apoptosis of rat hippocampal neurons and its mechanisms in vitro. Helliyon. 2015;1(1):1-16. https://doi.org/10.1016/i.heliyon.2015.e00020

8. Li M, Chang C, Han Y, Liao C, Yu J. Ginkgolide B promotes neuronal differentiation through the Wnt / $\beta$ - catenin pathway in neural stem cells of the postnatal mammalian subventricular zone. Sci Rep. 2018;8(14947):1-10. https://doi.org/10.1038/s41598-018-32960-8

9. Hua J, Yin N, Yang B, Zhang J, Ding J, Fan Y, et al. Ginkgolide B and bilobalide ameliorate neural cell apoptosis in $\alpha$ synuclein aggregates. Biomed Pharmacother. 2017;96(October):792-797. https://doi.org/10.1016/i.biopha.2017.10.050

10. Marambaud P, Zhao H, Davies P. Resveratrol Promotes Clearance of Alzheimer's Disease Amyloid- $\beta$ Peptides. J Biol Chem. 2005;280(45):37377-37382. https://doi.org/10.1074/ibc.M508246200

11. Alvira D, Folch J, Verdaguer E, Canudas AM, Camins A. Comparative analysis of the effects of resveratrol in two apoptotic models: inhibition of complex $i$ and potassium deprivation in cerebellar neurons. Neuroscience. 2007;147(3):746-756. https://doi.org/10.1016/j.neuroscience.2007.04.029 
12. Konyalioglu S, Armagan G, Yalcin A, Atalayin C, Dagci T. Effects of resveratrol on hydrogen peroxide-induced oxidative stress in embryonic neural stem cells. Neural Regen Res. 2013;8(6):485-495. https://doi.org/10.3969/j.issn.16735374.2013.06.001

13. Jang J, Surh Y. Protective effects of resveratrol on hydrogen peroxide-induced apoptosis in rat pheochromocytoma ( PC12 ) cells. Mutat Res. 2001;496:181-190. https://doi.org/10.1016/S1383-5718(01)00233-9

14. Tellone E, Galtieri A, Russo A, Giardina B, Ficarra S. Resveratrol : A Focus on Several Neurodegenerative Diseases. Oxid Med Cell Longev. 2015;2015:1-14. https://doi.org/10.1155/2015/392169

15. Song J, Cheon SY, Jung W, Lee WT, Lee JE. Resveratrol Induces the Expression of Interleukin-10 and Brain-Derived Neurotrophic Factor in BV2 Microglia under Hypoxia. Int J Mol Sci. 2014;15:15512-15529. https://doi.org/10.3390/ijms150915512

16. Gong Q, Wang Q, Shi J, Huang X, Liu Q, Ma H. Inhibition of caspases and intracellular free Ca2+ concentrations are involved in resveratrol protection against apoptosis in rat primary neurons culture. Acta Pharmacol Sin. 2007;28(11):1724-1730. https://doi.org/10.1111/i.1745-7254.2007.00666.x

17. Chao J, Li H, Cheng K., Yu M., Chang R., Wang M. Protective effects of pinostilbene, a resveratrol methylated derivative, against 6-hydroxydopamine-induced neurotoxicity in SH-SY5Y cells. J Nutr Biochem. 2010;21(6):482-489. https://doi.org/10.1016/i.jnutbio.2009.02.004

18. Agrawal M, Kumar V, Singh A, Kashyap M, Khanna V, Siddiqui M, et al. trans -Resveratrol Protects Ischemic PC12 Cells by Inhibiting the Hypoxia Associated Transcription Factors and Increasing the Levels of Antioxidant Defense Enzymes. ACS Chem Neurosci. 2013;4:285-294. https://doi.org/doi:10.1021/cn300143m

19. Agrawal M, Kumar V, Kashyap M, Khanna V, Randhawa G, Pant A. Ischemic insult induced apoptotic changes in PC12 cells : Protection by trans resveratrol. Eur J Pharmacol. 2011;666(1-3):5-11. https://doi.org/10.1016/j.ejphar.2011.05.015

20. Chen C, Jang J, Li M, Surh Y. Resveratrol upregulates heme oxygenase-1 expression via activation of NF-E2-related factor 2 in PC12 cells . Biochem Biophys Res Commun 2005. 2005;331(4):993-1000. https://doi.org/10.1016/i.bbrc.2005.03.237

21. Wang $M$, Huang $H$, HsiehSJ, Jeng K, Kuo J. Resveratrol inhibits interleukin-6 production in cortical mixed glial cells under hypoxia/hypoglycemia followed by reoxygenation. J Neuroimmunol 2001. 2001;112(1-2):28-34. https://doi.org/10.1016/S0165-5728(00)00374-X

22. Mao X, Zhou H, Li X, Liu Z. Huperzine A Alleviates Oxidative Glutamate Toxicity in Hippocampal HT22 Cells via Activating BDNF / TrkB- Dependent PI3K / Akt / mTOR Signaling Pathway. Cell Mol Neurobiol. 2016;36:915-925. https://doi.org/10.1007/s10571-015-0276-5

23. Damar U, Gersner R, Johnstone JT, Schachter S, Rotenberg A. Huperzine A as a neuroprotective and antiepileptic drug : a review of preclinical research. Expert Rev Neurother. 2016;16(6):671-680. https://doi.org/10.1080/14737175.2016.1175303

24. Xiao $X$, Wang R, Tang X. Huperzine $A$ and tacrine attenuate beta-amyloid peptide-induced oxidative injury. $J$ Neurosci Res. 2000;61(5):564-569. https://doi.org/10.1002/1097-4547(20000901)61

25. Xiao X, Zhang H, Tang X. Huperzine A attenuates amyloid beta-peptide fragment 25-35-induced apoptosis in rat cortical neurons via inhibiting reactive oxygen species formation and caspase-3 activation. J Neurosci Res. 2002;67(1):30-36. https://doi.org/10.1002/jnr.10075

26. Xiao X, Wang R, Han Y, Tang X. Protective effects of huperzine A on beta-amyloid ( 25-35 ) induced oxidative injury in rat pheochromocytoma cells. Neurosci Lett. 2000;286(3):155-158. https://doi.org/10.1016/S0304-3940(00)01088-0

27. Zhang L, Yu H, Sun Y, Lin X, Chen B, Tan C, et al. Protective effects of salidroside on hydrogen peroxide-induced apoptosis in SH-SY5Y human neuroblastoma cells. Eur J Pharmacol. 2007;564(1-3):18-25. https://doi.org/10.1016/i.ejphar.2007.01.089

28. Zhang L, Yu H, Zhao X, Lin X, Tan C, Cao G, et al. Neuroprotective effects of salidroside against beta-amyloid-induced oxidative stress in SH-SY5Y human neuroblastoma cells. Neurochem Int. 2010;57(5):547-555. https://doi.org/10.1016/i.neuint.2010.06.021

29. Qu Z, Zhou Y, Zeng Y, Lin Y, Li Y, Zhong Z, et al. Protective Effects of a Rhodiola Crenulata Extract and Salidroside on Hippocampal Neurogenesis against Streptozotocin-Induced Neural Injury in the Rat. PLoS One. 2012;7(1):1-17. https://doi.org/10.1371/journal.pone.0029641

30. Wu D-M, Han X-R, Wen X, Wang S, Fan S-H, Zhuang J, et al. Salidroside Protection Against Oxidative Stress Injury Through the Wnt / $\beta$ - Catenin Signaling Pathway in Rats with Parkinson 's Disease. Cell Physiol Biochem. 2018;46(5):1793-1806. https://doi.org/10.1159/000489365

31. Wang C, Lou Y, Xu J, Xu J, Feng Z, Chen Y, et al. Endoplasmic Reticulum Stress and NF- k B Pathway in Salidroside Mediated Neuroprotection : Potential of Salidroside in Neurodegenerative Diseases. Am J Chin Med. 2017;45(1-17). https://doi.org/10.1142/S0192415X17500793

32. Yu S, Liu M, Gu X, Ding F. Neuroprotective effects of salidroside in the PC12 cell model exposed to hypoglycemia and serum limitation. Cell Mol Neurobiol. 2008;28(8):1067-1078. https://doi.org/10.1007/s10571-008-9284-z 
33. Chen Z, Lu Y, Wang Z, Tao X, Wei D. Protective Effects of Salidroside on Hypoxia/Reoxygenation Injury by Sodium Hydrosulfite in PC12 Cells. Pharm Biol. 2007;45(8):604-512. https://doi.org/10.1080/13880200701538666

34. Chen X, Zhang Q, Cheng Q, Ding F. Protective effect of salidroside against $\mathrm{H} 2 \mathrm{O} 2$-induced cell apoptosis in primary culture of rat hippocampal neurons. Mol Cell Biochem. 2009;332(1-2):85-93. https://doi.org/10.1007/s11010-009-0177-3

35. Huang $\mathrm{H}, \mathrm{Xu} \mathrm{K}$, Jang Z. Curcumin-mediated neuroprotection against amyloid- $\beta$-induced mitochondrial dysfunction involves the inhibition of GSK-3ß. J Alzheimers Dis. 2019;32(4):2-3. https://doi.org/10.3233/JAD-2012-120688

36. Dikmen M, Kaya-tilki E, Engur S, Ozturk Y. Neuritogenic activity of epigallocatechin gallate and curcumin combination on rat adrenal pheochromocytoma cells. Fresenius Environ Bull. 2017;26(7):4726-4733.

37. Yang F, Lim GP, Begum AN, Ubeda OJ, Simmons MR, Ambegaokar SS, et al. Curcumin Inhibits Formation of Amyloid Oligomers and Fibrils, Binds Plaques, and Reduces Amyloid in Vivo. J Biol Chem. 2005;280(7):5892-5901.

https://doi.org/10.1074/ibc.M404751200

38. Zhang L, Fang Y, Xu Y, Lian Y, Xie N, Wu T. Curcumin Improves Amyloid $\beta$-Peptide (1-42) Induced Spatial Memory Deficits through BDNF-ERK Signaling Pathway. PLoS One. 2015;10(6):1-17. https://doi.org/10.1371/journal.pone.0131525

39. Nam S, Choi J, Yoo D, Kim W, Jung H, Kim J, et al. Effects of Curcumin (Curcuma longa) on Learning and Spatial Memory as Well as Cell Proliferation and Neuroblast Differentiation in Adult and Aged Mice by Upregulating Brain-Derived Neurotrophic Factor and CREB Signaling. J Med Food. 2014;17(6):641-649. https://doi.org/10.1089/jmf.2013.2965

40. Liu D, Wang Z, Gao Z, Xie K, Zhang Q, Jiang H, et al. Effects of curcumin on learning and memory deficits, BDNF, and ERK protein expression in rats exposed to chronic unpredictable stress. Behav Brain Res. 2014;1(271):116-121. https://doi.org/10.1016/j.bbr.2014.05.068

41. Sang Q, Liu X, Wang L, Qi L, Sun W, Wang W, et al. Curcumin Protects an SH-SY5Y Cell Model of Parkinson's Disease Against Toxic Injury by Regulating HSP90. Cell Physiol Biochem. 2018;51:681-691. https://doi.org/10.1159/000495326

42. Fonfria E, Marshall I, Boyfield I, Skaper S, Hughes J, Owen D, et al. Amyloid $\beta$-peptide(1-42) and hydrogen peroxideinduced toxicity are mediated by TRPM2 in rat primary striatal cultures. J Neurochem. 2005;95(3):715-723. https://doi.org/10.1111/i.1471-4159.2005.03396.x

43. Williams RSB, Bate C. An in vitro model for synaptic loss in neurodegenerative diseases suggests a neuroprotective role for valproic acid via inhibition of cPLA2 dependent signalling. Neuropharmacology. 2015;101:1-10. https://doi.org/10.1016/i.neuropharm.2015.06.013

44. Okello E, McDougall G, Kumar S, Seal C. In vitro protective effects of colon-available extract of Camellia sinensis (tea) against hydrogen peroxide and beta-amyloid (A $\beta$ (1-42)) induced cytotoxicity in differentiated PC12 cells. Phytomedicine. 2011;18(2011):691-696. https://doi.org/10.1016/i.phymed.2010.11.004

45. Xu M, Xiong Y, Liu J, Qian J, Zhu L, Gao J. Asiatic acid, a pentacyclic triterpene in Centella asiatica, attenuates glutamateinduced cognitive deficits in mice and apoptosis in SH-SY5Y cells. Acta Pharmacol Sin. 2012;33:578-587. https://doi.org/10.1038/aps.2012.3

46. Gao L, Zhou W, Symmes B, Freed CR. Re-cloning the N27 dopamine cell line to improve a cell culture model of Parkinson's disease. PLoS One. 2016;11(8):1-18. https://doi.org/10.1371/journal.pone.0160847

47. De Andrade DVG, Madureira de Oliveria D, Barreto G, Bertolino LA, Saraceno E, Capani F, et al. Effects of the extract of Anemopaegma mirandum (Catuaba) on Rotenone-induced apoptosis in human neuroblastomas SH-SY5Y cells. Brain Res. 2008;1198:188-196. https://doi.org/10.1016/j.brainres.2008.01.006

48. Kang SS, Lee JY, Choi YK, Kim GS, Han BH. Neuroprotective effects of flavones on hydrogen peroxide-induced apoptosis in SH-SY5Y neuroblostoma cells. Bioorg Med Chem Lett. 2004;14(9):2261-2264. https://doi.org/10.1016/j.bmcl.2004.02.003

49. Choi Y-S, Lee M-C, Kim H-S, Lee K-H, Park Y-G, Kim H-K, et al. Neurotoxicity screening in a multipotent neural stem cell line established from the mouse brain. J Korean Med Sci. 2010;25(3):440-448.

https://doi.org/10.3346/ikms.2010.25.3.440

50. Zhao Z-Y, Luan P, Huang S-X, Xiao S-H, Zhao J, Zhang B, et al. Edaravone protects HT22 neurons from H2O2-induced apoptosis by inhibiting the MAPK signaling pathway. CNS Neurosci Ther. 2013;19(3):163-169. https://doi.org/10.1111/cns.12044

51. Chen L, Liu L, Yin J, Luo Y, Huang S. Hydrogen peroxide-induced neuronal apoptosis is associated with inhibition of protein phosphatase 2A and 5, leading to activation of MAPK pathway. Int J Biochem Cell Biol. 2009;41(6):1284-1295. https://doi.org/10.1016/j.biocel.2008.10.029

52. Biedler JL, Roffler-tarlov S, Schachner M, Freedman LS. Multiple Neurotransmitter Synthesis by Human Neuroblastoma Cell Lines and Clones. Cancer Res. 1978;38(11 pt 1):2-5.

53. Phlman S, Abrahamsson L, Mattsson M, Esscher T. Retinoic acid-induced differentiation of cultured human neuroblastoma cells : a comparison with phorbolester-induced. Cell Differ 1. 1984;14(2):135-144.

54. Agholme L, Lindström T, Kågedal K, Marcusson J, Hallbeck M. In Vitro Model for Neuroscience : Differentiation of SHSY5Y Cells into Cells with Morphological and Biochemical Characteristics of Mature Neurons. J Alzheimers Dis. 2010;20(4):1069-1082. https://doi.org/doi:10.3233/JAD-2010-091363 
55. Constantinescu R, Constantinescu AT, Reichmann H, Janetzky B. Neuronal differentiation and long-term culture of the human neuroblastoma line SH-SY5Y. J Neural Transm. 2007;72:17-28. https://doi.org/doi:10.1007/978-3-211-73574-9 3

56. Xie H, Hu L, Li G. SH-SY5Y human neuroblastoma cell line : in vitro cell model of dopaminergic neurons in Parkinson 's disease . Chin Med J (Engl). 2010;123(8):1086-1092. https://doi.org/doi:10.3760/cma.j.issn.0366-6999.2010.08.021

57. Kitamura Y, Inden M, Miyamura A, Kakimura J, Taniguchi T, Shimohama S. Possible involvement of both mitochondriaand endoplasmic reticulum-dependent caspase pathways in rotenone-induced apoptosis in human neuroblastoma SHSY5Y cells . Neurosci Lett. 2002;333(1):25-28. https://doi.org/doi:10.1016/S0304-3940(02)00964-3

58. Sánchez-Reus MI, Peinado II, Molina-Jiménez MF, Benedí J. Fraxetin prevents rotenone-induced apoptosis by induction of endogenous glutathione in human neuroblastoma cells. Neurosci Res. 2005;53(1):48-56.

https://doi.org/10.1016/j.neures.2005.05.009

59. Carolindah M, Rosli R, Adam A, Nordin N. An Overview of in Vitro Research Models for Alzheimer'S Disease (Ad). Regen Res. 2013;2(2):8-13.

60. Eves EM, Tucker MS, Robacko JD, Downen M, Rosner MR, Wainer BH. Immortal rat hippocampal cell lines exhibit neuronal and glial lineages and neurotrophin gene expression. Neurobiology. 1992;89(10):4373-4377. https://doi.org/10.1073/pnas.89.10.4373

61. Ahn SM, Choi YW, Shin HK, Choi BT. New four-herb formula ameliorates memory impairments via neuroprotective effects on hippocampal cells. J Life Sci. 2016;26(4):475-483. https://doi.org/10.5352/JLS.2016.26.4.475

62. Torrent R, De Angelis Rigotti F, Dell'Era P, Memo M, Raya A, Consiglio A. Using iPS Cells toward the Understanding of Parkinson's Disease. J Clin Med. 2015;4(4):548-566. https://doi.org/10.3390/jcm4040548

63. Kwon Y-W, Chung Y-J, Kim J, Lee H-J, Park J, Roh T-Y, et al. Comparative study of efficacy of dopaminergic neuron differentiation between embryonic stem cell and protein-based induced pluripotent stem cell. PLoS One. 2014;9(1):e85736. https://doi.org/10.1371/journal.pone.0085736

64. Cooper O, Seo H, Andrabi S, Guardia-laguarta C, Sundberg M, Mclean JR, et al. Familial Parkinson's disease iPSCs show cellular deficits in mitochondrial responses that can be pharmacologically rescued. Sci Transl Med . 2012;4(141):1-25. https://doi.org/10.1126/scitranslmed.3003985.Familial

65. Joshi C, Enver T. Molecular complexities of stem cells . Curr Opin Hematol. 2003;10(3):220-228. https://doi.org/10.1097/00062752-200305000-00005

66. Kitazawa A, Shimizu N. Differentiation of Mouse Embryonic Stem Cells into Neurons Using Conditioned Medium of Dorsal Root Ganglia. J Biosci Bioeng. 2005;100(1):94-99. https://doi.org/10.1263/ibb.100.94

67. Yang Y, Gupta S, Kim K, Powers B, Cerqueira A, Wainger B, et al. A Small Molecule Screen in Stem Cell-derived Motor Neurons Identifies a Kinase Inhibitor as a Candidate Therapeutic for ALS. Cell Stem Cell. 2013;12(6):713-726. https://doi.org/10.1016/i.stem.2013.04.003.A

68. Aubert J, Stavridis MP, Tweedie S, Reilly MO, Vierlinger K, Li M, et al. Screening for mammalian neural genes via fluorescence-activated cell sorter purification of neural precursors from Sox1 - gfp knock-in mice. PNAS. 2003;100(Suppl 1):11836-11841. https://doi.org/10.1073/pnas.1734197100

69. Bain G, Kitchens D, Yao M, Huettner JE, Gottlieb D. Embryonic stem cells express neuronal properties in vitro. [Internet]. Vol. 168, Developmental biology. 1995. p. 342-357. https://doi.org/10.1006/dbio.1995.1085

70. Otsu M, Sai T, Nakayama T, Murakami K, Inoue N. Uni-directional differentiation of mouse embryonic stem cells into neurons by the neural stem sphere method. Neurosci Res. 2011;69(4):314-321. https://doi.org/10.1016/i.neures.2010.12.014

71. Mun-Fun H, Ferdaos N, Hamzah NS, Ridzuan N, Hisham NA, Abdullah S, et al. Rat Full Term Amniotic Fluid Harbors Highly Potent Stem Cells. Res Vet Sci. 2015;102:89-99. https://doi.org/10.1016/i.rvsc.2015.07.010

72. Eistetter HR. Pluripotent Embryonal Stem Cell Lines Can Be Established from Disaggregated Mouse Morulae. Dev Growth Differ. 1989;31(3):275-282. https://doi.org/10.1111/i.1440-169X.1989.00275.x

73. Pauklin S, Pedersen R a, Vallier L. Mouse pluripotent stem cells at a glance. J Cell Sci. 2011;124:3727-3732. https://doi.org/10.1242/jcs.074120

74. Evans MJ, Kaufman MH. Establishment in culture of pluripotential cells from mouse embryos. Nature. 1981;292:154-156. https://doi.org/10.1038/292154a0

75. Smith A, Heath J, Donaldson D, Wong G, Moreau J, Stahl M, et al. Inhibition of pluripotential embryonic stem cell differentiation by purified polypeptides. Nature. 1989;336:688-690. https://doi.org/10.1038/336688a0

76. Hadjantonakis A, Papaioannou V. The stem cells of early embryos. Differentiation. 2001;68(4-5):159-166. https://doi.org/10.1046/j.1432-0436.2001.680403.x

77. Rodda SJ, Kavanagh SJ, Rathjen JOY, Rathjen PD. Embryonic stem cell differentiation and the analysis of mammalian development. Int J Dev Biol. 2002;46(4):449-458.

78. Weitzer G. Embryonic StemCell-Derived Embryoid Bodies: An In Vitro Model of Eutherian Pregastrulation Development and Early Gastrulation. Handb Exp Pharmacol. 2006;174:21-51. https://doi.org/10.1007/3-540-31265-X 2

79. Outten JT, Gadue P, French DL. High-throughput screening assay for embryoid body differentiation of human embryonic 
stem cells. Curr Protoc Stem Cell Biol. 2012;1:1-17. https://doi.org/10.1002/9780470151808.sc01d06s20

80. Avilion AA, Nicolis SK, Pevny LH, Perez L, Vivian N, Lovell-badge R. Multipotent cell lineages in early mouse development depend on SOX2 function. Genes Dev. 2003;17:126-140. https://doi.org/10.1101/gad.224503.derm

81. Boyer LA, Lee TI, Cole MF, Johnstone SE, Stuart S, Zucker JP, et al. Core Transcriptional Regulatory Circuitry in Human Embryonic Stem Cells. Cell. 2005;122(6):947-956. https://doi.org/10.1016/j.cell.2005.08.020

82. Loh Y, Wu Q, Chew J, Vega VB, Zhang W, Chen X, et al. The Oct4 and Nanog transcription network regulates pluripotency in mouse embryonic stem cells. Nat Genet. 2006;38(4):431-440. https://doi.org/10.1038/ng1760

83. Wang Z, Oron E, Nelson B, Razis S, Ivanova N. Distinct Lineage Specification Roles in Human Embryonic Stem Cells. Stem Cell. 2012;10(4):440-454. https://doi.org/10.1016/i.stem.2012.02.016

84. Adjaye J, Huntriss J, Herwig R, Benkahla A, Brink TC, Wierling C, et al. Primary Differentiation in the Human Blastocyst: Comparative Molecular Portraits of Inner Cell Mass and Trophectoderm Cells. Stem Cells. 2005;23(10):1514-1525. https://doi.org/10.1634/stemcells.2005-0113

85. Loebel DAF, Watson CM, Young RA De, Tam PPL. Lineage choice and differentiation in mouse embryos and embryonic stem cells. Dev Biol. 2003;264(1):1-14. https://doi.org/10.1016/S0012-1606(03)00390-7

86. Pevny LH, Nicolis SK. Sox2 roles in neural stem cells. Int J Biochem Cell Biol. 2010;42(3):421-424. https://doi.org/10.1016/i.biocel.2009.08.018

87. Silva J, Nichols J, Theunissen TW, Guo G, Oosten AL Van, Barrandon O, et al. Nanog Is the Gateway to the Pluripotent Ground State. Cell. 2009;138(4):722-737. https://doi.org/10.1016/j.cell.2009.07.039

88. Angeles ADL, Xi R, Hochedlinger K, Jaenisch R. Hallmarks of pluripotency. Nature. 2015;525(7570):469-478. https://doi.org/10.1038/nature15515

89. Mitsui K, Tokuzawa Y, Itoh H, Segawa K, Murakami M, Takahashi K, et al. The Homeoprotein Nanog Is Required for Maintenance of Pluripotency in Mouse Epiblast and ES Cells. Cell. 2003;113(5):631-642. https://doi.org/10.1016/S00928674(03)00393-3

90. Coppi P De, Bartsch G, Siddiqui MM, Xu T, Santos CC, Perin L, et al. Isolation of amniotic stem cell lines with potential for therapy. Nat Biotechnol. 2007;25(1):100-106. https://doi.org/10.1038/nbt1274

91. Tsai M, Lee J, Chang Y, Hwang S. Isolation of human multipotent mesenchymal stem cells from second-trimester amniotic - uid using a novel two-stage culture protocol. Hum Reprod. 2004;19(6):1450-1456. https://doi.org/10.1093/humrep/deh279

92. Cananzi M, Atala A, Coppi P De. Stem cells derived from amniotic fluid : new potentials in regenerative medicine. Reprod Biomed Online. 2009;18(1):17-27. https://doi.org/10.1016/S1472-6483(10)60111-3

93. Ying Q-L, Stavridis M, Griffiths D, Li M, Smith A. Conversion of embryonic stem cells into neuroectodermal precursors in adherent monoculture. Nat Biotechnol. 2003;21(2):183-186. https://doi.org/10.1038/nbt780 